ARTUR ŻURAWIK

ORCID: 0000-0002-6349-6344

Uniwersytet Jagielloński artur@zurawik.pl

\title{
Dostęp podmiotów świadczących usługi prawnicze do służby publicznej w sądach administracyjnych
}

\begin{abstract}
Abstrakt: Wykonywanie zawodów prawniczych to wielki przywilej - wiążą się z nim jednak nie tylko prawa, lecz także specyficzne obowiązki. Wielu prawników świadczy swoje usługi w ramach prowadzonej działalności gospodarczej. Część z nich odnajduje się najlepiej w tak zwanych wolnych zawodach, inni natomiast widzą swoją przyszłość w służbie publicznej w sądach powszechnych bądź administracyjnych.

W praktyce pojawia się jednak problem nieścisłości przepisów regulujących procedurę obsady wolnych stanowisk sędziowskich, a to z kolei rodzi wątpliwości co do przyjętej w praktyce ich wykładni. Tym samym niepotrzebnie ogranicza się dostęp do służby publicznej wobec adwokatów, radców prawnych czy notariuszy wykonujących swą działalność gospodarczą w ramach kancelarii prawniczych. Wynika to z konieczności odpowiedniego stosowania przepisów ustrojowych dotyczących sądownictwa powszechnego w ramach procedur dotyczących obsady takich stanowisk w sądach administracyjnych. Innymi słowy chodzi tu o problem, czy do obsady stanowisk sędziowskich w sądach administracyjnych mają zastosowanie ograniczenia odnoszące się do zakazu ponownego zgłaszania kandydatur przed zakończeniem poprzednio rozpoczętych postępowań w sprawie powołania do pełnienia urzędu. Jest to $\mathrm{w}$ istocie zagadnienie dopuszczalnej ingerencji w konstytucyjne prawo dostępu do służby publicznej.
\end{abstract}

Słowa kluczowe: służba publiczna, adwokaci, radcowie prawni, notariusze, konstytucja, sądy powszechne, sądy administracyjne.

\section{Uwagi ogólne}

Wykonywanie zawodów prawniczych to wielki przywilej, wiążą się z nim jednak nie tylko prawa, lecz także specyficzne obowiązki. Wielu prawników świad- 
czy swoje usługi w ramach prowadzonej działalności gospodarczej. Część z nich odnajduje się najlepiej w tak zwanych wolnych zawodach, inni natomiast widzą swoją przyszłość w służbie publicznej, czy to w sądach powszechnych, czy administracyjnych.

W praktyce pojawia się jednak problem nieścisłości przepisów regulujących procedurę obsady wolnych stanowisk sędziowskich, a to z kolei rodzi wątpliwości co do przyjętej w praktyce ich wykładni. Tym samym niepotrzebnie ogranicza się dostęp do służby publicznej wobec adwokatów, radców prawnych czy notariuszy wykonujących swą działalność gospodarczą w ramach kancelarii prawniczych. Wynika to z konieczności odpowiedniego stosowania przepisów ustrojowych dotyczących sądownictwa powszechnego w ramach procedur dotyczących obsady takich stanowisk w sądach administracyjnych. Innymi słowy chodzi tu o problem, czy i w jakim zakresie do obsady stanowisk sędziowskich w sądach administracyjnych mają zastosowanie ograniczenia odnoszące się do zakazu ponownego zgłaszania kandydatur przed zakończeniem poprzednio rozpoczętych postępowań w sprawie powołania do pełnienia urzędu. Jest to w istocie zagadnienie dopuszczalnej ingerencji w konstytucyjne prawo dostępu do służby publicznej i celowości przyjętych przez ustawodawcę rozwiązań w odniesieniu do sądów szczególnych, jakimi są sądy administracyjne.

Ponieważ jest to tematyka istotna nie tylko z punktu widzenia funkcjonowania wymiaru sprawiedliwości, ale i dla samych kandydatów na stanowiska sędziowskie w sądach administracyjnych, którzy w dużej części wywodzą się z korporacji prawniczych, stąd warto ją omówić szerzej.

\section{Konstytucyjne prawo dostępu do służby publicznej}

Prawo dostępu do służby publicznej zostało określone w art. 60 Konstytucji Rzeczypospolitej Polskiej ${ }^{1}$. Zgodnie z nim obywatele polscy korzystający z pełni praw publicznych mają prawo dostępu do służby publicznej na jednakowych zasadach.

Prawo to określa również artykuł 25 Międzynarodowego paktu praw obywatelskich i politycznych ${ }^{2}$, w którego świetle każdy obywatel ma między innymi prawo i możliwości bez żadnej dyskryminacji (art. 2) i bez nieuzasadnionych ograniczeń dostępu do służby publicznej w swoim kraju na ogólnych zasadach równości.

Powszechnie przyjęte $\mathrm{w}$ piśmiennictwie stanowisko prowadzi do wniosku, że ani Konstytucja, ani polskie prawo w ogólności nie stwarzają wystarczających

1 Dz.U. z 1997 r. Nr 78, poz. 483 ze zm.

2 Dz.U. z 1977 r. Nr 38, poz. 167 zał. 
podstaw do precyzyjnej definicji „służby publicznej”. W tej sytuacji przyjmuje się szerokie jej rozumienie z nadaniem jej charakteru pojęcia zbiorczego, obejmującego bardzo różne rodzajowo postaci tej służby, co z kolei implikuje odpowiednie zróżnicowanie ,jednakowych zasad”, o których mowa w art. 60 Konstytucji ${ }^{3}$.

$\mathrm{Na}$ tej podstawie wywodzi się, że służbą publiczną jest trwałe ${ }^{4}$ wykonywanie wszelkich zajęć związanych bezpośrednio lub tylko pośrednio z realizacją zadań władzy publicznej, wypełnianiem funkcji publicznych lub zaspokajaniem potrzeb publicznych (powszechnych, masowych, powtarzalnych) oraz działanie w interesie publicznym (art. 22, art. 213 ust. 1 Konstytucji) bądź dla osiągnięcia celu publicznego (art. 216 ust. 2 Konstytucji) ${ }^{5}$.

Trybunał Konstytucyjny uznał zatem, że

nie podlega dyskusji, że prawo dostępu do służby publicznej obejmuje także stanowiska sędziowskie. Szczególna ranga oraz rola sądów w zakresie realizacji konstytucyjnych wolności i praw wymaga, aby [...] zasady konstytucyjne były respektowane w sposób szczególnie skrupulatny przy obsadzaniu stanowisk sędziowskich. Biorąc pod uwagę konstytucyjną zasadę niezawisłości sędziów, należy wykluczyć wszelką arbitralność i dowolność w tym zakresie ${ }^{6}$.

W tym samym orzeczeniu Trybunał Konstytucyjny zauważył, że ubieganie się o przeniesienie na wyższe stanowisko zbiega się z reguły z kandydowaniem na to stanowisko nie tylko osób, które już zostały przyjęte do służby publicznej, ale także osób, które ubiegają się o dane stanowisko, nie należąc jeszcze do służby publicznej (w tym świadczących usługi prawnicze w ramach tak zwanych wolnych zawodów). $\mathrm{Z}$ tego względu gwarancje konstytucyjne zapewniają jednakową ochronę kandydatów już zatrudnionych w służbie publicznej, jak i kandydatów spoza tej służby.

\section{Obecna regulacja dostępu do stanowisk sędziowskich}

Sygnalizowany na wstępie problem pojawił się wraz z wejściem w życie w dniu 1 października 2014 roku ustawy z dnia 14 marca 2014 roku o zmianie

3 W. Sokolewicz, Komentarz do art. 60 Konstytucji, [w:] Konstytucja Rzeczypospolitej Polskiej. Komentarz, red. L. Garlicki, t. 4, Warszawa 2005, s. 14-15; M. Jabłoński, Prawo dostępu do stużby publicznej, [w:] Prawa i wolności obywatelskie w Konstytucji RP, red. B. Banaszak, A. Preisner, Warszawa 2002, s. 627 i podana tam literatura.

4 A raczej „względnie trwałe".

5 W. Sokolewicz, Komentarz do art. 60..., s. 14-15. Konstytucyjne pojęcia podobne to: ,instytucja publiczna” (zob. preambuła), „władza publiczna” (art. 7, art. 15, art. $30 \mathrm{i}$ in. ), ,administracja publiczna” (art. 63), ,funkcja publiczna” (art. 61 ust. 1, art. 103 ust. 3, art. 132), „działalność publiczna” (art. 178, art. 195 ust. 3 i in.), „obowiązki publiczne” (art. 150), „godność publiczna” (art. 33).

6 Wyrok TK z dnia 29 listopada 2007 roku, sygn. SK 43/06, OTK-A 2007/10/130. 
ustawy — Prawo o ustroju sądów powszechnych oraz niektórych innych ustaw ${ }^{7}$, co skutkowało wieloma zmianami w procedurach związanych z obsadą stanowisk sędziowskich w ramach sądownictwa powszechnego, a to przez stosowanie art. 29 ustawy z dnia 25 lipca 2002 roku — Prawo o ustroju sądów administracyjnych ${ }^{8}$ (dalej: p.u.s.a.), odnosi skutek, przynajmniej częściowy, także w ramach procedur dotyczących obsady stanowisk w wojewódzkich sądach administracyjnych ${ }^{9}$. Stan ten trwa również dziś.

W motywach do wspomnianej nowelizacji ustawy — Prawo o ustroju sądów powszechnych ${ }^{10}$ wskazano, że zasadniczym i priorytetowym celem zmian w przepisach ustawy było osiągnięcie optymalnego skrócenia trwania postępowania $\mathrm{w}$ sprawie powołania do pełnienia urzędu na stanowisku sędziego sądu powszechnego. Zauważa się również, co szczególnie istotne z punktu widzenia niniejszego opracowania, że fundamentalną zmianą jest ograniczenie możliwości równoczesnego zgłaszania kandydatur na więcej niż jedno obwieszczone stanowisko sędziowskie do czasu zakończenia procedury wynikającej z pierwszego zgłoszenia. W karcie zgłoszenia wypełnianej w systemie teleinformatycznym przewidziano stosowne oświadczenie w tym przedmiocie. Podkreśla się, że wskazane rozwiązanie w odpowiedni sposób ograniczy i ustabilizuje dotychczas ukształtowaną praktykę, zgodnie z którą jeden kandydat zgłaszał swoją kandydaturę na więcej niż jedno wolne stanowisko równolegle. Skutkiem tego było podejmowanie w stosunku do tego samego kandydata w różnych sądach równocześnie analogicznych czynności procedury nominacyjnej, co generowało znaczne nakłady środków i zaangażowanie zasobów ludzkich, a to z kolei — zdaniem projektodawcy — negatywnie wpływało na tok realizacji ustawowych zadań poszczególnych komórek organizacyjnych sądów. Zauważono, że w świetle konstytucyjnych gwarancji niezawisłości sędziego, wprowadzona regulacja wpłynie pozytywnie na ilość składanych wniosków o przeniesienie sędziów na inne miejsca służbowe. Korzystnie oddziaływać też będzie na racjonalizację decyzji kandydatów co do wyboru miejsca służbowego, w którym chcą pełnić urząd. Jednocześnie regulacja nie będzie (zdaniem autorów projektu nowelizacji) tworzyła ograniczenia dostępu do zawodu - po zakończeniu procedury nominacyjnej kandydat będzie miał prawo zgłosić swoją kandydaturę ponownie.

7 Dz.U. z 2014 r. poz. 512.

8 Tekst jedn. Dz.U. z 2018 r. poz. 2107 ze zm.

9 Zaznaczę, że art. 49 p.u.s.a. z kolei stwierdza między innymi, że w sprawach nieuregulowanych w ustawie, do Naczelnego Sądu Administracyjnego oraz do sędziów, urzędników i pracowników tego Sądu, stosuje się odpowiednio przepisy dotyczące Sądu Najwyższego. Zagadnienia obsady stanowisk w tych sądach jednak tu pominę.

10 Zob. http://bip.kprm.gov.pl/kpr/bip-rady-ministrow/projekty-ustaw-przeslan/2887,Projekty-ustaw-przeslane-do-Sejmu-RP.html (dostęp: 27.09.2019). 


\section{Ograniczenia w zakresie równoległego kandydowania na różne stanowiska sędziowskie}

Zgodnie $\mathrm{z}$ powyższymi ustaleniami ograniczenia $\mathrm{w}$ zakresie ponownego zgłaszania kandydatur przed zakończeniem poprzednio rozpoczętych postępowań w sprawie powołania do pełnienia urzędu sędziowskiego zaczęły obowiązywać z dniem 1 października 2014 roku i trwają nadal. Artykuł 5 ust. 1 ustawy nowelizującej z dnia 14 marca 2014 roku zakładał, że powoływanie na wolne stanowiska sędziego sądu powszechnego, o których obwieszczono przed dniem wejścia w życie ustawy, odbywało się na podstawie przepisów dotychczasowych. Z kolei ust. 2 wskazanego przepisu przejściowego stwierdza, że art. 57aa $\S 4$ ustawy z dnia 27 lipca 2001 roku - Prawo o ustroju sądów powszechnych ${ }^{11}$ (dalej: p.u.s.p.), w brzmieniu nadanym ustawą nowelizującą, a dotyczący omawianych ograniczeń równoległego kandydowania, ma zastosowanie do postępowań w sprawie powołania do pełnienia urzędu na stanowisku sędziowskim, dotyczących stanowisk, o których obwieszczono po dniu wejścia w życie ustawy nowelizującej, czyli po 1 października 2014 roku.

Sposób postępowania przed wymienioną nowelizacją określał ówczesny art. $57 \S 1$ p.u.s.p.:

każdy, kto spełnia warunki do objęcia stanowiska sędziego sądu powszechnego, o którym mowa w art. $55 \S 2$, może zgłosić swoją kandydaturę na jedno wolne stanowisko sędziowskie, w ciągu miesiąca od obwieszczenia, o którym mowa w art. 56. Zgłaszający swoją kandydaturę wypełnia w dwóch egzemplarzach kartę zgłoszenia kandydata na wolne stanowisko sędziowskie oraz dołącza do niej informację z Krajowego Rejestru Karnego dotyczącą jego osoby i zaświadczenie stwierdzające, że jest zdolny, ze względu na stan zdrowia, do pełnienia obowiązków sędziego, z zastrzeżeniem art. $58 \S 4 \mathrm{a}$.

Na gruncie takiej regulacji stwierdzano, że ,jest oczywiste — co poprzednio przyjmowano w drodze wykładni - że dopuszczalne jest zgłoszenie kandydatury tylko na jedno wolne stanowisko sędziowskie spośród stanowisk wskazanych przez Ministra Sprawiedliwości w danym obwieszczeniu [... ${ }^{12}$. Nie było jednak przeszkód, by ponawiać swoje zgłoszenia po ukazaniu się kolejnych obwieszczeń. To prowadziło do sytuacji, że kandydaci w tym samym okresie brali udział w różnych procedurach konkursowych na stanowiska sędziowskie, co faktycznie powodowało, szczególnie na szczeblu sądów rejonowych, znaczne zwiększenie liczby kandydatów starających się o konkretne stanowisko.

Obecnie, w świetle art. $57 \S 1$ p.u.s.p., każdy, kto spełnia warunki do objęcia stanowiska sędziego sądu powszechnego, o którym mowa w art. $55 \S 2$, może zgłosić swoją kandydaturę na jedno stanowisko sędziowskie w terminie

11 Tekst jedn. Dz.U. z 2019 r. poz. 52 ze zm.

12 T. Ereciński, J. Gudowski, J. Iwulski, Prawo o ustroju sądów powszechnych. Ustawa o Krajowej Radzie Sadownictwa. Komentarz, Warszawa 2009, s. 196. 
trzydziestu dni od dnia obwieszczenia, o którym mowa w art. 20a $\S 4$. Z kolei $\S 1$ la tego przepisu wskazuje, że osoba, która zgłosiła swoją kandydaturę na wolne stanowisko sędziowskie w sądzie powszechnym, nie może, do czasu zakończenia postępowania w sprawie powołania do pełnienia urzędu na stanowisku sędziowskim w sądzie powszechnym, zgłosić swej kandydatury na wolne stanowisko sędziowskie w Sądzie Najwyższym, Naczelnym Sądzie Administracyjnym ani wojewódzkim sądzie administracyjnym. Zgłoszenie kandydatury na wolne stanowisko sędziowskie $\mathrm{w}$ tych sądach powoduje zakończenie postępowania w sprawie powołania do pełnienia urzędu na stanowisku sędziowskim w sądzie powszechnym. Artykuł $57 \S 1$ b p.u.s.p. stwierdza znów, że osoba, która zgłosiła swoją kandydaturę na wolne stanowisko sędziowskie w Sądzie Najwyższym, Naczelnym Sądzie Administracyjnym albo wojewódzkim sądzie administracyjnym, nie może, do czasu zakończenia postępowania w sprawie powołania do pełnienia urzędu na stanowisku sędziowskim w tym sądzie, zgłosić swej kandydatury na wolne stanowisko sędziowskie w sądzie powszechnym.

Artykuł 57aa $\S 4$ p.u.s.p. doprecyzowuje, że ponowne zgłoszenie kandydatury na wolne stanowisko sędziowskie może nastąpić nie wcześniej niż po dniu zakończenia poprzednio rozpoczętego postępowania w sprawie powołania do pełnienia urzędu na stanowisku sędziowskim. Za dzień rozpoczęcia postępowania w sprawie powołania do pełnienia urzędu na stanowisku sędziowskim przyjmuje się dzień złożenia karty zgłoszenia na dane stanowisko sędziowskie. Za dzień zakończenia postępowania wobec kandydata w sprawie powołania do pełnienia urzędu na stanowisku sędziowskim przyjmuje się dzień upływu wobec kandydata terminu do złożenia zastrzeżenia od pozostawienia zgłoszenia bez rozpatrzenia albo dzień uprawomocnienia się wobec kandydata uchwały Krajowej Rady Sądownictwa w przedmiocie:

1. nieuwzględnienia zastrzeżenia od pozostawienia zgłoszenia bez rozpatrzenia albo

2. umorzenia postępowania, albo

3. nieprzedstawienia wniosku o powołanie do pełnienia urzędu na stanowisku sędziowskim Prezydentowi Rzeczypospolitej Polskiej, albo

4. przedstawienia wniosku o powołanie do pełnienia urzędu na stanowisku sędziowskim Prezydentowi Rzeczypospolitej Polskiej ${ }^{13}$.

Wskazane przepisy nie odnoszą się jednak wprost do przypadku równoległego kandydowania na stanowiska sędziowskie w różnych sądach administracyjnych, na przykład do dwóch, trzech czy nawet czterech sądów administracyjnych. Powstaje więc zasadnicza kwestia, czy do obsady stanowisk sędziowskich

13 Przy tym, zgodnie z art. 57ac $§ 2$ p.u.s.p., jeżeli wobec zgłaszającego kandydaturę toczy się między innymi inne postępowanie w sprawie powołania do pełnienia urzędu na stanowisku sędziowskim, właściwy prezes sądu zawiadamia zgłaszającego o pozostawieniu zgłoszenia bez rozpatrzenia, za pośrednictwem systemu teleinformatycznego, podając przyczynę pozostawienia zgłoszenia bez rozpatrzenia. 
w sądach administracyjnych znajdują zastosowanie w pełnym zakresie powyższe ograniczenia? Praktyka pokazuje, że wielu adwokatów, radców prawnych, czy notariuszy, dotychczas świadcząc swoje usługi w ramach tak zwanych wolnych zawodów, pragnie związać swoją przyszłość z tą gałęzią sądownictwa, wykorzystując w praktyce nabytą wiedzę i doświadczenie. By zwiększyć swoje szanse powodzenia $\mathrm{w}$ procedurze naboru, chcieliby $\mathrm{w}$ wielu przypadkach kandydować w tym samym czasie do różnych sądów administracyjnych, co było możliwe w przeszłości.

Aby odpowiedzieć na to pytanie, należy dokonać analizy art. 29 p.u.s.a., w kontekście ogólnych zasad dotyczących ograniczania praw i wolności konstytucyjnych. Zgodnie z art. 29 § 1 p.u.s.a.:

W sprawach nieuregulowanych w ustawie do wojewódzkich sądów administracyjnych oraz sędziów, asesorów sądowych, starszych referendarzy sądowych, referendarzy sądowych, starszych asystentów sędziów, asystentów sędziów stosuje się odpowiednio przepisy o ustroju sądów powszechnych, z tym że:

1) przepisów dotyczących systemu teleinformatycznego obsługującego postępowanie w sprawie powołania do pełnienia urzędu na stanowisku sędziego sądu powszechnego albo asesora sądowego nie stosuje się $[\ldots]$;

4) do postępowania w przedmiocie powołania do pełnienia urzędu na stanowisku asesora sądowego stosuje się odpowiednio przepisy o postępowaniu w przedmiocie powołania do pełnienia urzędu na stanowisku sędziego sądu powszechnego.

Artykuł 29 § 2 p.u.s.a. odnosi się do urzędników i innych pracowników wojewódzkich sądów administracyjnych. Artykuł $29 \S 3$ p.u.s.a. doprecyzowuje, że „określone w przepisach, o których mowa w $\S 1$ i 2, uprawnienia Ministra Sprawiedliwości przysługują Prezesowi Naczelnego Sądu Administracyjnego".

Ponieważ w Prawie o ustroju sądów administracyjnych zagadnienia dotyczące obsady stanowisk sędziowskich w tych sądach są uregulowane dość ogólnikowo, stąd niezbędne jest tu odpowiednie stosowanie przepisów Prawa o ustroju sądów powszechnych. Proces ten musi jednak odpowiadać następującym warunkom: 1) ustawa ustrojowa dotycząca sądownictwa powszechnego ma być stosowana subsydiarnie (pomocniczo), to jest tylko wtedy, gdy ustawa - Prawo o ustroju sądów administracyjnych nie reguluje danej kwestii; 2 . stosuje się ją do: a) wojewódzkich sądów administracyjnych, b) sędziów, asesorów sądowych, starszych referendarzy sądowych, referendarzy sądowych, starszych asystentów sędziów, asystentów sędziów, urzędników i innych pracowników; 3. zastosowanie regulacji ustawy — Prawo o ustroju sądów powszechnych musi być „odpowiednie”"14.

Odesłanie z art. 29 p.u.s.a. ma zatem charakter przedmiotowo-podmiotowy. Z jednej strony, nakazuje ono „odpowiednie” stosowanie przepisów Prawa o ustroju sądów powszechnych do wojewódzkich sądów administracyjnych, czyli

14 Zob. T. Kuczyński, Komentarz do art. 29 ustawy - Prawo o ustroju sądów administracyjnych, [w:] Prawo o ustroju sądów administracyjnych. Komentarz, T. Kuczyński, M. Masternak-Kubiak, Warszawa 2009, s. 245. 
odsyła w zakresie przedmiotowym, a z drugiej — wskazuje, do jakich podmiotów należy stosować omawiane uregulowanie.

Z przepisu tego wynika również, że odesłanie zawarte w art. 29 p.u.s.a., a odnoszące się do wojewódzkich sądów administracyjnych, nie obejmuje bezpośrednio - nazwijmy to - substratu osobowego sądów administracyjnych. Dotyczy natomiast, jak twierdzi T. Kuczyński, na przykład zasad ustroju sądów (zasady wyłączności sędziów w wykonywaniu zadań z zakresu wymiaru sprawiedliwości — art. $2 \S 1$ p.u.s.p., zasady samorządności sędziowskiej — art. 3 p.u.s.p., zasady ustanowienia języka polskiego jako języka urzędowego przed sądem — art. 5 p.u.s.p.), niektórych zasad odnoszących się do organów sądu, niektórych zasad nadzoru nad działalnością administracyjną (na przykład postępowania weryfikacyjnego w związku ze wskazaniem na uchybienie w zakresie sprawności postępowania — art. 37 § 4 p.u.s.p.), zasad odnoszących się do czynności sądów (na przykład zasady wydawania wyroków w imieniu Rzeczypospolitej Polskiej — art. 42 $\S 1$ p.u.s.p., zasady wyposażenia sądu we władzę porządkową, w tym prawo ukarania karą porządkową grzywny lub karą pozbawienia wolności — art. 49 p.u.s.p. $)^{15}$. Chodzi więc tu raczej o ogólne unormowania dotyczące funkcjonowania sądów i ich organów, a do substratu osobowego odnoszące się najwyżej pośrednio.

Innymi słowy ustawodawca w art. 29 p.u.s.a. pojęcie „,wojewódzkich sądów administracyjnych" traktuje przedmiotowo, z wyłączeniem osób pełniących tam służbę i tam zatrudnionych, gdyż w dalszej części przepisu wskazuje już wprost, że ma on zastosowanie także do sędziów, referendarzy, asystentów itp. Druga część omawianego przepisu odnosi się więc bezpośrednio do sędziów sądów administracyjnych i pozostałych osób tam wymienionych.

Zatem można zapytać, na jakiej podstawie art. 29 p.u.s.a. miałby odnosić się również do innych podmiotów aniżeli podmioty wskazane wprost $\mathrm{w}$ tym przepisie, czyli do kandydatów na stanowiska sędziowskie. Ci wywodzą się nie tylko z sądów, na przykład powszechnych, lecz także z innych zawodów prawniczych. Są często radcami prawnymi, adwokatami, notariuszami itp. Prowadząc swoje kancelarie, świadczą usługi prawnicze w ramach działalności gospodarczej. Ustawodawca daje im jednocześnie prawo podmiotowe dostępu do służby publicznej w sądach administracyjnych. Na jakiej podstawie i czy w ogóle dopuszczalne byłoby odpowiednie stosowanie przepisów Prawa o ustroju sądów powszechnych w zakresie ograniczającym prawa konstytucyjne tych osób, a konkretnie prawo dostępu do służby publicznej? Artykuł 29 p.u.s.a. o kandydatach na stanowiska sędziowskie milczy, a zawiera on katalog podmiotowo zamknięty. Jedynie w art. 29 $\S 1$ pkt 4 p.u.s.a. doprecyzowano — co można powtórzyć — że do postępowania w przedmiocie powołania do pełnienia urzędu na stanowisku asesora sądowego stosuje się odpowiednio przepisy o postępowaniu w przedmiocie powołania do

15 Ibidem, s. 248. 
pełnienia urzędu na stanowisku sędziego sądu powszechnego. Przepis ten dotyczy jednak kandydatów na asesorów, a nie na stanowiska sędziowskie ${ }^{16}$.

Należy zatem uznać, że przepis ten jest wadliwy i powoduje konieczność dokonywania wykładni rozszerzającej, tak by można było (w procedurach naboru na stanowiska sędziowskie w wojewódzkich sądach administracyjnych) stosować odpowiednio przepisy Prawa o ustroju sądów powszechnych, obejmując nimi również kandydatów na stanowiska sędziowskie. Dobrze, że przynajmniej podstawowe kryteria selekcyjne, kryteria oceny kandydatów, znalazły się w Prawie o ustroju sądów administracyjnych (art. 6), nakazując badanie na przykład tego, czy kandydat wyróżnia się wysokim poziomem wiedzy w dziedzinie administracji publicznej oraz prawa administracyjnego i innych dziedzin prawa związanych $z$ działaniem organów administracji publicznej ${ }^{17}$. Jest to istotne z punktu widzenia orzecznictwa Trybunału Konstytucyjnego, który podkreślał, że chodzi tu o realizację konstytucyjnego prawa dostępu do służby publicznej i z tego powodu podstawowe kryteria selekcji kandydatów powinny być określone w samej ustawie ${ }^{18}$.

Oczywiście konstytucyjne prawo dostępu do służby publicznej nie jest prawem absolutnym i może być ze względu na ważny interes publiczny ograniczane ustawowo; odbywa się to na zasadach ogólnych (art. 31 ust. 3 Konstytucji) ${ }^{19}$. Przy tym nie budzi moich wątpliwości, że art. 57 aa $§ 4$ p.u.s.p. ${ }^{20}$ ogranicza dostęp do służby publicznej, skoro zakazuje kandydowania na więcej niż jedno stanowisko sędziowskie aż do zakończenia poprzedniej procedury, nie dając nikomu gwarancji pozytywnego wyniku naboru. Zanim procedura zakończy się, może okazać się, że przez dłuższy czas nie będzie żadnego wolnego stanowiska sędziowskiego, którym taki kandydat byłby zainteresowany, z uwagi na przykład na możliwość dojazdu. Rotacja sędziów w sądach powszechnych jest o wiele większa niż w sądach administracyjnych i nabory są tam prowadzone częściej, przynajmniej na szczeblu rejonowym.

O ile wskazane ograniczenia na gruncie ustawy - Prawo o ustroju sądów powszechnych wprost odnoszą się do kandydatów na stanowiska sędziowskie w tych sądach, a zatem przynajmniej formalnie spełniają standardy konstytucyjne ${ }^{21}$, to już nie ma ich bezpośredniego przełożenia na kandydatów na stanowiska sędziowskie w sądach administracyjnych, którzy chcieliby równolegle kandydować do dwóch lub więcej sądów administracyjnych. Odesłanie w tym zakresie do

16 Por. wyrok SN z dnia 22 lutego 2017 roku, sygn. III KRS 2/17, LEX nr 2271451.

17 Por. B. Adamiak, J. Borkowski, Metodyka pracy sędziego w sprawach administracyjnych, Warszawa 2015, s. $23 \mathrm{n}$.

18 Wyrok TK z dnia 29 listopada 2007 roku, sygn. SK 43/06, OTK-A 2007/10/130.

19 W. Sokolewicz, Komentarz do art. 60..., s. 18.

20 Podobnie jak art. $57 \S 1 \mathrm{a}$ i $\S 1$ b p.u.s.p.

${ }^{21}$ Co do materialnoprawnej ich zgodności z Konstytucją nie będę się w tym miejscu wypowiadał, nawiążę do tego pokrótce w dalszej części opracowania. 
ustawy - Prawo o ustroju sądów powszechnych objęło jedynie kandydatów na asesorów, a nie kandydatów na sędziów.

Co więcej, o ile stosowanie przepisów Prawa o ustroju sądów powszechnych, odnoszących się do procedur naboru na stanowiska sędziowskie w sądach administracyjnych, byłoby jeszcze do zaakceptowania w zakresie mniej istotnym, jedynie „technicznym”, tak by można było jednak procedury te w praktyce prowadzić22, realizując tym samym prawo dostępu do służby publicznej, to już trudno zaakceptować stosowanie wykładni rozszerzającej ${ }^{23}$ art. 29 p.u.s.a. w związku z art. 57aa $\S 4$ p.u.s.p. (oraz art. 57 § 1a i § 1 b p.u.s.p.), wywodząc z tych przepisów zakaz ponownego zgłaszania kandydatur w sądach administracyjnych przed zakończeniem poprzednio rozpoczętych postępowań $\mathrm{w}$ sprawie powołania do pełnienia urzędu sędziego sądu administracyjnego. Stosując wykładnię rozszerzającą art. 29 p.u.s.a. i rozciągając ten przepis na kandydatów na stanowiska sędziowskie w sądach administracyjnych, którzy chcą równolegle kandydować na stanowiska w tych sądach, ogranicza się tym samym materialnoprawne konstytucyjne prawo dostępu do służby publicznej takich osób ${ }^{24}$. Z tych powodów należałoby więc raczej stosować wykładnię ścisłą. Tym bardziej stosowanie analogii byłoby wadliwe.

Co więcej, w motywach do wspomnianej nowelizacji ustawy — Prawo o ustroju sądów powszechnych, która weszła w życie z dniem 1 października 2014 roku, wskazywano, że jej celem było skrócenie procedur naboru, w związku z bardzo dużą liczbą zgłoszeń na poszczególne stanowiska w sądach powszechnych, co wydłużało proces rekrutacyjny. Problem ten jednak nie występuje w ramach sądownictwa administracyjnego. Na poszczególne stanowiska sędziowskie do czasu wejścia w życie wskazanych przepisów, zgłaszało się kilku, czy kilkunastu kandydatów,

22 Tym bardziej że wiele przepisów dotyczących naboru jednak jest obecnych w Prawie o ustroju sądów administracyjnych.

${ }^{23} \mathrm{O}$ wykładni tej zob. szerzej na przykład K. Płeszka, Wykładnia rozszerzająca, Warszawa 2010, passim; L. Morawski, Zasady wykładni prawa, Torun 2010, s. 198 n.

${ }^{24}$ Zasady konstytucyjne będące komponentem demokratycznego państwa prawnego (art. 2) mogą mieć charakter zasad materialnych (na przykład prawo do sądu, zasada równości itp.) oraz zasad formalnych (normy i zasady działalności prawodawczej, normy i zasady stosowania prawa). Zob. np. Polskie dyskusje o państwie prawa, red. S. Wronkowska, Warszawa 1995, s. 5 n.; Zasada demokratycznego państwa prawnego w Konstytucji RP, red. S. Wronkowska, Warszawa 2006, passim; M. Wyrzykowski, Zasada demokratycznego państwa prawnego - kilka uwag, [w:] Księga XX-lecia orzecznictwa Trybunału Konstytucyjnego, red. M. Zubik, Warszawa 2006, s. 233 n.; M. Wyrzykowski, Zasada demokratycznego państwa prawnego, [w:] Zasady podstawowe polskiej konstytucji, red. W. Sokolewicz, Warszawa 1998, s. 65-91; Proces prawotwórczy w świetle orzecznictwa Trybunatu Konstytucyjnego, red. I. Chojnacka, Warszawa 2009, s. 7 n.; W. Sokolewicz, [w:] Konstytucja Rzeczypospolitej Polskiej. Komentarz, red. L. Garlicki, t. 5, tezy do art. 2, Warszawa 2007, s. 32 n.; Zasady ustroju III Rzeczypospolitej Polskiej, red. D. Dudek, Warszawa 2009, s. 156 n.; I. Wróblewska, Zasada państwa prawnego w orzecznictwie Trybunału Konstytucyjnego RP, Toruń 2010, passim; A. Żurawik, Ustrój sądownictwa w Polsce, Warszawa 2013, s. 1-8 i podana tam literatura. Zob. też przykładowe wyroki TK: z dnia 25 listopada 1997 roku, K 26/97, OTK ZU nr 5-6/1997, s. 444 n.; z dnia 22 czerwca 1999 roku, K 5/99, OTK ZU nr 5/1999, s. 536. 
rzadko większa liczba. Ograniczenie dostępu do służby publicznej w sądach administracyjnych, poprzez ewentualny zakaz równoległego kandydowania na różne stanowiska $\mathrm{w}$ ramach sądownictwa administracyjnego, nie ma zatem racjonalnych przesłanek merytorycznych i - moim zdaniem - uchybiałby dodatkowo konstytucyjnej zasadzie proporcjonalności zawartej w art. 31 ust. $3^{25}$. Stosowane byłoby ograniczenie prawa konstytucyjnego w zakresie nieadekwatnym do zamierzonego rezultatu $\mathrm{i}$ to, gdy procedury nominacyjne w ramach sądownictwa administracyjnego nie były jakąkolwiek przyczyną uchwalenia omawianych zmian. Wynika to wprost z wskazanych wcześniej motywów nowelizacji. Procedur nominacyjnych w wojewódzkich sądach administracyjnych w ten sposób wydatnie nie przyspieszy się, a kandydat na kolejne ogłoszenie o wolnym stanowisku sędziowskim, co niewykluczone, będzie musiał czekać długi czas. Liczba etatów w sądach administracyjnych i rotacja sędziów nie są tak duże jak na przykład w sądach rejonowych.

\section{Wnioski}

Z takich analizy wynika przede wszystkim to, że celem zmian ustawodawczych dotyczących zakazu ponownego zgłaszania kandydatur przed zakończeniem poprzednio rozpoczętych postępowań w sprawie powołania do pełnienia urzędu było przyspieszenie procedur naboru w ramach sądownictwa powszechnego, a nie administracyjnego. Problem występował w zasadzie jedynie przy naborach na stanowiska sędziowskie w sądach rejonowych, w których na jedno wolne stanowisko zgłaszało się co do zasady kilkadziesiąt kandydatur, a niekiedy i więcej.

Ograniczanie dostępu do służby publicznej w sądach administracyjnych przez ewentualny zakaz równoległego kandydowania na różne stanowiska w sądach administracyjnych uchybiałby także - moim zdaniem - konstytucyjnej zasadzie proporcjonalności zawartej w art. 31 ust. 3. Stosowane byłoby ograniczenie w zakresie nieadekwatnym do zamierzonego rezultatu i wcale w zauważalnym stopniu nie przyspieszyłoby procedur naboru.

Takich problemów można zatem uniknąć, stosując się do nakazu dokonywania wykładni przepisów wskazanych ustaw zgodnie z Konstytucją ${ }^{26}$. Dzięki temu będzie możliwe zapobieżenie niepotrzebnemu ograniczaniu praw przynależnych kandydatom na stanowiska sędziowskie w sądach administracyjnych. Świadczą oni często usługi prawnicze w ramach działalności gospodarczej w kancelariach adwokackich, notarialnych czy radcowskich, mając duże doświadczenie, które może być wykorzystane w służbie publicznej. Dostęp do zawodu sędziego dla

${ }^{25} \mathrm{O}$ zasadzie tej zob. szerzej na przykład J. Zakolska, Zasada proporcjonalności w orzecznictwie Trybunatu Konstytucyjnego, Warszawa 2008, passim.

26 Szerzej zob. L. Morawski, op. cit., s. 127-130; K. Complak, Normy pierwszego rozdziału Konstytucji RP, Wrocław 2007, s. 28. 
takich prawników winien być więc ułatwiony, a nie utrudniony — i to z powodów proceduralnych.

\section{Bibliografia}

Adamiak B., Borkowski J., Metodyka pracy sędziego w sprawach administracyjnych, Warszawa 2015.

Complak K., Normy pierwszego rozdziału Konstytucji RP, Wrocław 2007.

Ereciński T., Gudowski J., Iwulski J., Prawo o ustroju sądów powszechnych. Ustawa o Krajowej Radzie Sadownictwa. Komentarz, Warszawa 2009.

Jabłoński M., Prawo dostępu do stużby publicznej, [w:] Prawa i wolności obywatelskie w Konstytucji RP, red. B. Banaszak, A. Preisner, Warszawa 2002.

Kuczyński T., Komentarz do art. 29 ustawy - Prawo o ustroju sądów administracyjnych, [w:] Prawo o ustroju sądów administracyjnych. Komentarz, red. T. Kuczyński, M. Masternak-Kubiak, Warszawa 2009.

Morawski L., Zasady wykładni prawa, Torun 2010.

Płeszka K., Wykładnia rozszerzająca, Warszawa 2010.

Polskie dyskusje o państwie prawa, red. S. Wronkowska, Warszawa 1995.

Proces prawotwórczy w świetle orzecznictwa Trybunatu Konstytucyjnego, red. I. Chojnacka, Warszawa 2009.

Sokolewicz W., Komentarz do art. 2, [w:] Konstytucja Rzeczypospolitej Polskiej. Komentarz, red. L. Garlicki, t. 5, Warszawa 2007.

Sokolewicz W., Komentarz do art. 60 Konstytucji, [w:] Konstytucja Rzeczypospolitej Polskiej. Komentarz, red. L. Garlicki, t. 4, Warszawa 2005.

Wróblewska I., Zasada państwa prawnego w orzecznictwie Trybunału Konstytucyjnego RP, Toruń 2010.

Wyrzykowski M., Zasada demokratycznego państwa prawnego, [w:] Zasady podstawowe polskiej konstytucji, red. W. Sokolewicz, Warszawa 1998.

Wyrzykowski M., Zasada demokratycznego państwa prawnego — kilka uwag, [w:] Księga XX-lecia orzecznictwa Trybunatu Konstytucyjnego, red. M. Zubik, Warszawa 2006.

Zakolska J., Zasada proporcjonalności w orzecznictwie Trybunału Konstytucyjnego, Warszawa 2008.

Zasada demokratycznego państwa prawnego w Konstytucji RP, red. S. Wronkowska, Warszawa 2006. Zasady ustroju III Rzeczypospolitej Polskiej, red. D. Dudek, Warszawa 2009.

Żurawik A., Ustrój sądownictwa w Polsce, Warszawa 2013.

\section{Access to public service in administrative courts by entities providing legal services}

Summary

Practicing the legal profession constitutes a great privilege, yet it is associated not only with rights, but also specific obligations. Many lawyers provide their services as part of their business 
activities.Some of them find themselves best suited to so-called freelancing, while others see their future in public service in common or administrative courts.

In practice, however, problems arise of the inaccuracy of provisions regulating the procedure for filling vacant judicial positions, and this in turn raises doubts as to the interpretation of them in practice. Thus, access to public service is unnecessarily restricted for lawyers, legal advisers, or notaries, who carry out their business activities within law firms. This stems from the need to properly apply the system provisions pertaining to ordinary jurisdiction as part of the procedures for filling such positions in administrative courts. In other words, it is a question of whether restrictions regarding the prohibition of re-submission of candidacies before the end of previously initiated procedures for appointment to office apply to staffing of judicial positions in administrative courts.

This is, in essence, the issue of permissible interference in the constitutional right of access to public service.

Keywords: public service, lawyers, legal advisers, notaries, constitution, common courts, administrative courts. 